Winter 2010

\title{
Mexican Drug Violence and Adversarial Experiments
}

Ronald F. Wright

Follow this and additional works at: https://scholarship.law.unc.edu/ncilj

\section{Recommended Citation}

Ronald F. Wright, Mexican Drug Violence and Adversarial Experiments, 35 N.C. J. INT'L L. 363 (2009). Available at: https://scholarship.law.unc.edu/ncilj/vol35/iss2/4 accepted for inclusion in North Carolina Journal of International Law by an authorized editor of Carolina Law Scholarship Repository. For more information, please contact law_repository@unc.edu. 


\section{Mexican Drug Violence and Adversarial Experiments}

\section{Cover Page Footnote}

International Law; Commercial Law; Law 


\title{
Mexican Drug Violence and Adversarial Experiments
}

\author{
Ronald F. Wright $\uparrow$
}

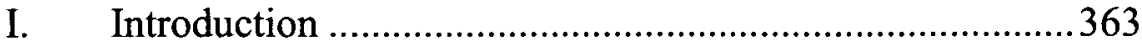

II. Recent Drug Violence in Mexico ........................................364

III. Movement Away From the Inquisitorial System in

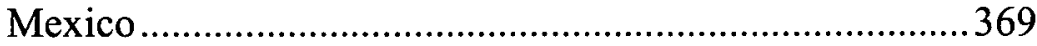

A. The Traditional Latin American Model .......................370

B. The Traditional Mexican Model .................................371

C. Mexican Code Revisions ..............................................374

D. Framing the Code Revisions ........................................376

IV. Cause-Effect Relationship Between Drug Violence and Procedural Reforms in Mexico..........................................378

A. The Inevitability Hypothesis ...........................................379

B. Violence-as-Causation Hypothesis .................................380

V. Conclusion: Federalism and the Legitimacy Question in

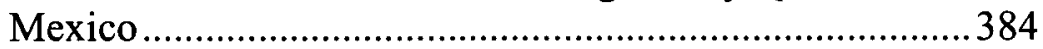

\section{Introduction}

Observers of the Mexican criminal justice system today cannot help but notice two remarkable developments. First, the country is suffering through wrenching violence connected with the drug trade. The violence amounts to far more than background noise, rising to a level that some regard as a "civil war,"' or evidence that Mexico could become a "failed state." Second, Mexico has

†Professor of Law and Associate Dean for Academic Affairs, Wake Forest University School of Law. This essay grows out of a speech delivered at the University of North Carolina in April 2008. I am grateful to Professor Michael Corrado for organizing the conference, and to the participants in the conference for their perceptive observations about my project.

1 Arthur Brice, Drug Violence Spins Mexico Toward 'Civil War', CNN, Feb. 19, 2009, http://www.cnn.com/2009/WORLD/americas/02/18/mexico.drug.violence/ index.html.

2 "The government thus becomes both an arena for competition among the cartels and an instrument used by one cartel against another. That is the prescription for what is called a 'failed state'-a state that no longer can function as a state." George Friedman, Mexico: On the Road to a Failed State?, STRATFOR, May 13, 2008, 
embarked on procedural changes at both the federal and state levels. The effort has achieved more than procedural tinkering at the edges, creating some base-level changes at the constitutional and statutory level in the legal machinery that responds to crime.

Many characterize this procedural transformation as a shift from an inquisitorial to an adversarial model of criminal procedure. I suggest, however, that the reforms do not simply endorse the strengths of a particular adversarial fact-finding method. Rather, the principal virtue of the new criminal codes in Mexico turn on their efforts to balance powers. In particular, the codes create meaningful competition for the public prosecutors in Mexico during the investigation, trial, and punishment of alleged criminals.

The drug violence in Mexico and the revision of state and federal criminal codes in that country are both stories that deserve intense scrutiny, standing alone. Taken together, they are riveting. This article will review these developments and consider the connections between them, both in the past and the future. Looking back, did one development cause the other, or did they both flow from a single cause? Looking forward, will the procedural reform make it easier to respond to the drug violence? Or will the drug violence distort or disable the procedural reform?

Writ large, these two developments in Mexico raise this basic challenge for lawyers everywhere: Does procedure matter at all in conditions of extreme violence and disorder? Does a debate about adversarial versus inquisitorial justice amid ghastly violence resemble a debate about iPods versus other MP3 players in a household where nobody has enough to eat? Alternatively, is an orderly and legitimate procedure the best hope under extreme conditions of disorder?

\section{Recent Drug Violence in Mexico}

The troubles of the Mexican criminal justice system date back

http://www.stratfor.com/weekly/mexico_road_failed_state; see also Ted Galen Carpenter, Drug Gangs Winning the War for Mexico, Houston CHRON., Feb. 6, 2009, available at http://www.chron.com/disp/story.mpl/editorial/outlook/6251540.html; see also Sara Miller Llana, How Mexico is Waging War on Drug Cartels, ChRISTIAN SCI. MONITOR, Aug. 16, 2009, at 10 (Pentagon report warned in Winter 2009 that Mexico could become a "failed state"). 
to the earliest days of the nation. ${ }^{3}$ The events that capture our attention at present, however, began with the national presidential election campaign of 2006 . Three candidates represented the three major parties in the effort to succeed Vincente Fox. Felipe Calderón, like Fox, was the nominee of the National Action Party (the Partido Acción Nacional, or PAN), a right-of-center party. ${ }^{4}$ The Democratic Revolution Party (the Partido de la Revolución Democrática, or PRD), a left-of-center party, nominated Andrés Manuel López Obrador. ${ }^{5}$ Roberto Madrazo represented the Institutional Revolutionary Party (the Partido Revolucionario Institucional, or PRI). ${ }^{6}$ The election presented a novel experience for the voters, because the PRI had dominated Mexican politics for most of the twentieth century. ${ }^{7}$ After Vincente Fox broke the political monopoly of the PRI, familiar political truths in Mexico no longer applied.

Calderón won an extremely close election, amid reports of voting irregularities. ${ }^{8}$ The PRD disputed the legitimacy of this outcome, and Obrador refused to recognize Calderón as President. ${ }^{9}$ As a result of the extended turmoil after the election, Calderón believed that he needed to take some unifying actions early in his tenure. He moved against drug cartels to create a sense of law and order that many voters were missing.

The new President's offensive against the cartels faced daunting odds. "[Drug] cartels [brought] in billions of dollars more than the Mexican government spent to defeat them." ${ }^{\text {"C }}$ Cartel

3 See generally LAWYERS COMMITTEE FOR HUMAN RIGHTS, LEgALIZED InJUSTICE: Mexican Criminal Procedure and Human Rights (2001) (highlighting deeplyembedded traditions in Mexican criminal procedure as the root of human rights concerns).

4 Mexican Presidential Election: Political Crossroad, Houston Chron., July 2, 2006, at A26.

5 Id.

6 Id.

7 See Dudey Althaus \& Marion Lloyd, In What May be a Sign of What's to Come, Calderon Takes Office Amid Brawling Congress, Houston CHRON., Dec. 2, 2006, at A1.

8 See Mexico's Presidential Election: The Closest of Victories: Mexico's Presidential Election, ECONOMIST, July 8, 2006, at 31.

9 See Chris Hawley, Mexican Says He's 'Legitimate' President; Lopez Obrador Touring Country, Hasn't Conceded, USA TodAY, Dec. 19, 2007, at 8A.

10 Marc Lacey, In an Escalating Drug War, Mexico Fights the Cartels, and Itself, N.Y. TimES, Mar. 30, 2009, at A1. 
leaders spent a portion of their wealth bribing police, mayors, and some higher-level officials, including some who worked in the customs service and others in the prison system. ${ }^{11}$ Even in the army, considered less corrupt than the police, "defense officials estimated that 100,000 soldiers have quit to join cartels over the previous seven years." 12 President Calderón himself received death threats from cartels during the election campaign, suggesting that the new President held a personal commitment to this policy priority. ${ }^{13}$

Because the cartels' bribery of the police remained a pervasive problem, Calderón was unable to call on existing structures of law enforcement. $^{14}$ Instead, he sent the army into the fight, devoting more than 40,000 troops to the effort. ${ }^{15}$ Mexico started extraditing record numbers of drug suspects to the United States for trial, revealing the loss of confidence of political leaders in the Mexican judicial system. ${ }^{16}$

The military offensive against the drug cartels offered some early positive results. The campaign produced record seizures of drugs, money, and guns, along with tens of thousands of arrests which depleted the ranks of the four main Mexican drug cartels. ${ }^{17}$ Mexican authorities announced in April 2009 that they had arrested over 60,000 people for drug crimes over the past two years. ${ }^{18}$ The government claimed to have reduced the number of "zones of impunity" from 2,204 down to 233. ${ }^{19}$ Enforcement efforts against cartels uncovered a large number of high-level officials and police officers who had collaborated in criminal

11 See Tracy Wilkinson, Mexico Under Siege: Calderon Shifts Tactics in Fight With Drug Gangs, L.A. TIMES, May 28, 2009, at A20.

12 Lacey, supra note 10.

13 See id.

14 See James C. McKinley Jr., Mexico Hits Drug Gangs with Full Fury of War, N.Y. Times, Jan. 22, 2008, at A1.

15 Enrique Krauze, Op-Ed., The Mexican Evolution, N.Y. TIMES, Mar. 24, 2009, at A27.

16 See Oscar Avila, Mexico Shifts Course, Aggressively Extradites Suspects to U.S., CHI. TriB., Jan. 13, 2009.

17 See Marc Lacey, The War's Origins, N.Y. TIMES, Mar. 30, 2009, at A12.

18 William Booth \& Steve Fainaru, Mexican Drug Fight Nets 60,000 Suspects, WASH. POST, May 1, 2009, at A10.

19 Lacey, supra note 10. 
enterprises. $^{20}$

Drug organizations traffic in violence, and the cartels responded violently to the government's offensive. There were 6,200 drug-related killings in 2008 (double the number of drugrelated killings in 2007). ${ }^{21}$ Some of these killings involved multiple executions or mutilations of the victims' bodies. ${ }^{22}$ Some of the deaths were attributed to intra-organization discipline, while others resulted from struggles among the major cartels. ${ }^{23}$ Many of the killings, however, targeted law enforcement agents, along with a few killings of civilian bystanders. ${ }^{24}$

Soldiers in Mexico started to cover their faces while on patrol, because their families faced retribution if the drug traffickers recognized them. ${ }^{25}$ The Mexican army allowed soldiers to grow their hair longer, so they were not so easy to identify as soldiers while off-duty. ${ }^{26}$ In one riveting incident early in 2009 in Ciudad Juárez, drug traffickers demanded the resignation of police chief Roberto Orduña Cruz, and vowed to kill one police officer every 48 hours until he resigned. ${ }^{27}$ They carried out the threat by killing the deputy chief of the department, another police officer, and a prison guard. ${ }^{28}$ Orduña resigned after a few days. ${ }^{29}$ The federal government then deployed 5,000 soldiers to Ciudad Juárez and the surrounding state of Chihuahua. ${ }^{30}$

Mexicans actively debated the wisdom of Calderón's

20 See Wilkinson, supra note 11.

21 Editorial, Death and American Guns in Mexico, N.Y. TIMES, June 25, 2009, at A22. See Diana Washington Valdez, UTEP Drug Conference: New Cartel Methods

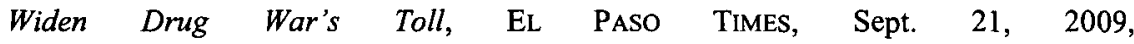
http://www.elpasotimes.com/ci_13384214 (explaining that 12,000 violent deaths occurred during first two years of Calderon initiative).

22 See William Booth, 12 Federal Agents are Slain in Mexico, WASH. POST, July 15,2009 , at A9.

23 See Lacey, supra note 10.

24 See Booth, supra note 22.

25 See Lacey, supra note 10.

26 See id.

27 Marc Lacey, With Deadly Persistence, Mexican Drug Cartels Get Their Way, N.Y. TIMES, Mar. 1, 2009, at A1.

28 See id.

29 See id.

$30 \mathrm{Id}$. 
aggressive strategy against the cartels. ${ }^{31}$ For some, it was all a colossal mistake: "Calderón took a stick and whacked the beehive." ${ }^{32}$ The involvement of the military in criminal law enforcement also apparently resulted in an increase in human rights violations against suspects. ${ }^{33}$ The government's plan seemed inspired by the United States plan to counter narcotics in Colombia, a dispiriting analogy that led some to predict a prolonged violence in the country with little or no gains in public order. $^{34}$ Overall, however, the public still supports the Calderón initiative against the cartels. ${ }^{35}$

Remarkably, the extreme conditions of violence led the federal government in Mexico to pass a law in August 2009 legalizing the possession of some small amounts of drugs for personal consumption. ${ }^{36}$ The government's stated strategy was to focus more of its limited law enforcement resources on small-time sellers of drugs. ${ }^{37}$

In the United States, concern about Mexico intensified. ${ }^{38}$ The legalization of certain drug possession prompted worries that greater drug use would spread to the United States, as easy access

31 See Lacey, supra note 10.

32 Id.

33 See Booth \& Fainaru, supra note 18.

34 See Lacey, supra note 10; see also Leslie Berestein, Can Mexico Learn from Colombia's Drug War?, S.D. UNION-TRIB., Feb. 16, 2009, at A1. See generally The Center for International Policy's Colombia Program, "Plan Mexico" and Plan Colombia: Similarities and Differences (2007), http://www.cipcol.org/?p=487 (last visited Feb. 19, 2010) (comparing the two plans and warning of the potential dangers of Mexico utilizing a strategy similar to Colombia's).

35 See Mica Rosenberg, Mexican Army Will Fight Drug War for Years: Report, REUTERS, Apr. 21, 2009, available at http://www.reuters.com/article/newsMaps/ idUSN1654810320090421; see also Editorial, A Promising Turn for Mexico, S.F. Chron., July 23, 2009, at D4.

36 See Oscar Avila, Mexico Weighs a Change of Focus on Drugs, CHI. TRIB., October 19, 2008 at A7; Sara Miller Llana, Legalization of Drugs Spreads in Latin America. Will the US Follow? CHRISTIAN SCI. Monitor, Sept. 23, 2009, at 6; Tracy Wilkinson \& Richard Marosi, Mexico Shifts Tactics in Drug Battle, L.A. Times, Aug. 23, 2009, at A21.

37 See Marc Lacey, In Mexico, Ambivalence on a Drug Law, N.Y. TIMES, Aug. 24, 2009, at A4.

38 See generally Op-Ed., Surrender: Mexican Congress Weakens Drug Laws, S.D. UNION-TRIB., Aug. 26, 2009, at B6 (explaining the controversy over Mexico's decriminalization of marijuana). 
would be just across the border. ${ }^{39}$ Secretary of State Hillary Clinton spoke in early 2009 about the possible spillage of Mexican violence over the border into the United States, while acknowledging the American role in creating the violent environment. ${ }^{40}$ It is largely demand from the United States for drugs that makes the drug business profitable, and the United States' commerce in firearms that makes the cartel business more deadly. ${ }^{41}$

\section{Movement Away From the Inquisitorial System in Mexico}

Which legal actors and institutions in Mexico can respond to such drug violence? The relevant players in Mexican criminal justice, and their capacity to respond to crime, are changing just as rapidly as the drug violence in the country.

Mexico, broadly speaking, draws on the civil law tradition, which employs an inquisitorial model of criminal justice. ${ }^{42}$ Like much of Latin America, Mexico inherited its procedural template from Spain. ${ }^{43}$ Today, however, Mexico offers a different take on the civil law system than most other Latin American countries. ${ }^{44}$ The distinctions between the Mexican model and the inquisitorial

39 See Julie Watson, Mexico's Liberal New Drug-Use Law Worries U.S. Police, The Deseret News (Salt Lake City), Aug. 27, 2009, at A1.

40 See Ken Ellingwood, Clinton: U.S. Shares Blame for Mexico Ills, L.A. TimES, Mar. 26, 2009, at A1. Secretary Clinton stated that "[w]e know very well that the drug traffickers are motivated by the demand for illegal drugs in the United States, that they are armed by the transport of weapons from the United States to Mexico." Id.

41 See id.; see James C. McKinley, Jr., U.S. Stymied as Guns Flow to Mexican Cartels, N.Y. TimEs, Apr. 15, 2009, at A1.

42 See Craig M. Bradley, Overview, in Criminal Procedure: A Worldwide STUDY xv (Craig M. Bradley ed., 2d ed. 2007) (discussing the inquisitorial (or civil law) approach and the accusatorial (or common law) approach to criminal procedure). Professor Giulio Illuminati distinguishes accusatorial from inquisitorial systems. Giulio Illuminati, The Frustrated Turn to Adversarial Procedure in Italy (Italian Criminal Procedure Code of 1988), 4 WASH. UNIV. GLOBAL STUD. L. REV. 567, 568-69 (2005) (viewing as accusatorial any model that strictly separates the investigating phase from the trial. Under the inquisitorial model, "decisions are based on evidence gathered unilaterally and in secret during the preliminary investigations by the investigating judge.").

43 See STEPHEN Zamora ET AL., MeXicAn LAW 11 (2004); Maximo Langer, Revolution in Latin American Criminal Procedure: Diffusion of Legal Ideas from the Periphery, 55 Ам. J. CoMP. L. 617, 628 (2007).

44 See Bradley, supra note 42, at 351-52. 
systems in other Latin American countries explain why criminal justice reform in Mexico concentrates more on the role of public prosecutors. $^{45}$

\section{A. The Traditional Latin American Model}

The classic Latin American inquisitorial codes contain two features that distinguish them from systems that tend to be more adversarial. ${ }^{46}$ First, the Latin American criminal codes generally provide a written process that accumulates evidence over time, as opposed to an oral process that concentrates proof into a shorter time frame. ${ }^{47}$ Second, the inquisitorial codes assure the quality of evidence through professional standards of the investigating officer-that is, the judge-rather than through a testing of the evidence from the defendant armed with several pre-declared rights, or through presentation of evidence to lay adjudicators such as jurors. ${ }^{48}$

Latin American inquisitorial codes typically divide the criminal process into two stages: A pretrial investigation (sumario

45 Id. at $352-55$.

46 See generally ZAMORA ET AL., supra note 43, at 364-68 (stages of the Mexican criminal process); see also JoHN H. MERRYMAN \& ROGELIO PEREZ-PERDOMO, THE CIVIL LAW TRADITION 127-29 (Stanford University Press 3d ed. 2007) (1969) (general descriptions of inquisitorial criminal justice systems).

47 See ZAMORA ET AL., supra note 43, at 364; cf. JACQUeline HodgSon, FrenCH CRIMINAl Justice: A CoMPaRative ACCOUNT OF THE INVESTIGATION AND PROSECUTION OF CRIME IN FRANCE 31-32 (2005) (describing the similar system used for evidence collection in France's inquisitorial system).

48 See ZAMORA ET AL., supra note 43, at 365, 368 (explaining the virtual absence of jury trials and summarizing the evidentiary stage of Mexican criminal procedure); see also Langer, supra note 43, at 629 (explaining the limited rights of defendants in traditional inquisitorial Latin American systems); see also MERRYMAN \& PEREzPERDOMO, supra note 46, at 127-29 (comparing the common law accusatorial system with the civil law inquisitorial system); $c$. John H. Langbein \& Lloyd L. Weinreb, Continental Criminal Procedure: "Myth" and Reality, 87 Yale L.J. 1549, 1551-67 (1978) (describing the French and German versions of the inquisitorial tradition); $c f$. Jenia Iontcheva Turner, Judicial Participation in Plea Negotiations: A Comparative View, 54 AM. J. COMP. L. 199, 215 (2006) (summarizing the German inquisitorial model). See generally Abraham S. Goldstein, Reflections on Two Models: Inquisitorial Themes in American Criminal Procedure, 26 STAN. L. REV. 1009, 1020 (1974) (focusing on the role of the judge and the rights of the accused in the traditional inquisitorial model); David Alan Sklansky, Anti-Inquisitorialism, 122 HARV. L. REV. 1634 (2009) (contrasting the inquisitorial system with the American adversarial system, and focusing on the rights of defendants). 
or instrucción) and a verdict and sentencing phase (plenario or juicio). ${ }^{49}$ The keystone of the process during both phases is the dossier (expediente) "that the police and investigating judge compile." 50

The judge takes charge of the investigation, which is "kept secret from the defendant and [the defense] attorney." 51 The defense has no right to be present during the production of evidence or to be apprised of charges before being interrogated; with limited exceptions, pretrial detention of the defendant is obligatory. ${ }^{52}$ In theory, the prosecutors hold no charging discretion, so every time the police or judges learn about a possible offense, they have to initiate criminal proceedings. ${ }^{53}$

At the verdict phase, the same judge who supervised the investigation phase remains in control of the case. ${ }^{54}$ At this point, the defendant and her attorney gain full access to the written dossier and can request the production of evidence. ${ }^{55}$ The verdict phrase is still "predominantly written [and] de facto [remains] secret from the public." The resolution of factual disputes does not include a jury. ${ }^{57}$

\section{B. The Traditional Mexican Model}

In Mexico, the central distinguishing feature of the system is the expansive role of the public prosecutors. ${ }^{58}$ Mexican prosecutors at the state and federal levels oversee police, investigations, and prosecutions. ${ }^{59}$ These duties do not fall to the

49 Langer, supra note 43, at 629.

50 Id.; see also HODGSON, supra note 47, at 32; see generally ZAMORA ET AL., supra note 43 , at $364-68$ (stages of the Mexican criminal process).

51 See Langer, supra note 43, at 629.

52 Id.

53 Id. at 629-30.

54 Id. at 630 .

55 Id.

56 Id.

57 See id.

58 See LAWYERS COMMITTEE FOR HUMAN RIGHTS, supra note 3, at 13-14; David Brennan, Mexico's Twin Challenges: Reforming its Criminal Justice System and Combating Drug-Cartel Violence, ORANGE COUNTY LAWYER, Jan. 2009 at 38, 39.

59 See Brennan, supra note 58, at 38-39; Miguel Sarré \& Jan Perlin, Mexico, in Criminal Procedure: A Worldwide StUdy 351 (Craig M. Bradley ed., 2d ed. 2007); 
investigating judge, as they would in the traditional Latin American model..$^{60}$

In general, Mexican prosecutors face less competition from other institutions than do prosecutors in other systems in the Western hemisphere. ${ }^{61}$ Compared to prosecutors in the United States, Mexican prosecutors do not face an especially active or empowered defense bar. ${ }^{62}$ Compared to other Latin American prosecutors, the prosecutors in Mexico do not defer to judges in the overall conduct of investigations. ${ }^{63}$

Granted, at the trial stage, the prosecutorial role in the traditional Mexican model is more limited than during investigation. $^{64}$ Judges in the trial stage render written decisions based on codes, applied mostly to written submissions of facts by the prosecutor and defense counsel. ${ }^{65}$ The cases are decided in camera. ${ }^{66}$ In Mexico, a prosecutor need only show "sufficient evidence of the crime," not proof beyond a reasonable doubt. ${ }^{67}$

The results that these institutions have achieved in Mexico have not been especially encouraging. Many human rights groups have chronicled the ills of Mexico's criminal justice system over the last two decades. ${ }^{68}$ Some common themes appear in these

David A. Shirk \& Alejandra Rios Cázares, Introduction: Reforming the Administration of Justice in Mexico, in REFORMING THE ADMINISTRATION OF JUSTICE IN MEXICO 1, 20 (Wayne A. Cornelius \& David A. Shirk eds., 2007).

60 See Langer, supra note 43, at 628-30.

61 See Shirk \& Cázares, supra note 59, at 20.

62 Id.

63 See LAWYers CommitTeE for Human Rights, supra note 3, at 14-15; see Carlos Rios Espinoza, Redesigning Mexico's Criminal Procedure: The States' Turning Point, 15 Sw. J. L. \& TRADE AM. 53, 57-58 (2008). See generally Shirk \& Cázares, supra note 59 , at 20 (explaining police investigation and prosecution in Mexico).

64 See Espinoza, supra note 63, at 58-60.

65 Brennan, supra note 58, at 39; see also Espinoza, supra note 63, at 82.

66 See ZAMORA ET AL., supra note 43, at 362-68; Leonard L. Cavise, The Transition from the Inquisitorial to the Accusatorial System of Trial Procedure: Why Some Latin American Lawyers Hesitate, 53 WAYNE L. REV. 785,792-93 (2007); Brennan, supra note 58 , at 39 .

67 See ZAMORA, ET AL., supra note 43, at 368; Brennan, supra note 58, at 40.

68 See, e.g. Amnesty Int'1, Unfair Trials: Unsafe Convictions, AI Index AMR 41/007/2003, Mar. 25, 2003; see LAWYERS COMMITTEE FOR HUMAN RIGHTS, supra note 3, at 73-77 (regarding allegations of coercion); see Espinoza, supra note 63, at 75; see Joseph R. Crowley Program, Special Report, Presumed Guilty?: Criminal Justice and 
reports: Corruption of officials, impunity of criminals, and inaccurate evidence. ${ }^{69}$ These problems do not flow inevitably from the inquisitorial heritage of the Mexican system, but one can see the connection between the most common malfunctions of the system and the lack of a counterweight to prosecutors, particularly at the investigative stage. ${ }^{70}$

Take, for instance, the perennial problems of bribery and corruption. The prosecutors' dominant role in both investigation and adjudication leads some of them to slight personal liberty protections. $^{71}$ The system, built around an assumption of professional competence of a government official, leaves prosecutors (and police, judges, customs officials, and prison administrators) susceptible to bribery and corruption. ${ }^{72}$

The Mexican system leaves far too many crimes undiscovered, with too many criminals untouched. There is a widespread perception among Mexican citizens, confirmed in survey after survey, that the system actors do not reliably investigate reports of crimes. $^{73}$ Even when investigations occur, the system ultimately produces few convictions. $^{74}$

Some attribute this inefficiency to the mandatory prosecution rule, which prevents officials from prioritizing cases in a rational way, leading to an overloaded system that allows bribery and other corruption to determine which cases drop out of the system. ${ }^{75}$ Others suggest that the slow accumulation of proof in a primarily written system prevents efficient case processing, meaning that the cases take so long to wind through the system that prosecutors and judges lose their urgency by the time the cases emerge from the end of the assembly line. ${ }^{76}$

Human Rights in Mexico, 24 FordHAM INT'L L.J. 801 (2000).

69 See Brennan, supra note 58, at 40.

70 Guillermo Zepeda Lecuona, Criminal Investigation and the Subversion of the Principles of the Justice System in Mexico, in REFORMING THE ADMINISTRATION OF JustiCE IN MeXICo 133 (Wayne A. Cornelius \& David A. Shirk eds., 2007).

71 See Brennan, supra note 58, at 40.

72 See Bradley, supra note 42 , at xvii-xx.

73 See Brennan, supra note 58 , at 40.

74 Id.

75 See LAWYERS COMMITTEE FOR HuMAN Rights, supra note 3, at 17; Zepeda Lecuona, supra note 70, at 141-51.

76 See Brennan, supra note 58, at 39-40. See generally LAWYERS COMMITTEE FOR 
Finally, the Mexican system relies too often on inaccurate evidence and coerced testimony. ${ }^{77}$ The system offers defendants no jury trial and other due process protections designed to test the origins and accuracy of evidence. ${ }^{78}$ The presumption of regularity and professionalism allows cases to go forward without regular checks. ${ }^{79}$ In Mexico, this opens the way for torture by police to obtain confessions, meaning that some convictions are based on coerced confessions and other false evidence. ${ }^{80}$

Why doesn't the defendant stop this from happening? Defense lawyers are generally precluded from confronting accusers and witnesses before the trial judge, leaving them with little opportunity to challenge corrupted evidence. ${ }^{81}$ In addition, defense counsel (especially appointed public counsel) are too often limited in what they can offer any single client because of their large caseloads. ${ }^{82}$

\section{Mexican Code Revisions}

While complaints about bribery, impunity, and coerced confessions have dogged the Mexican system for many years, some astonishing changes have appeared recently in Mexico's criminal courts. ${ }^{83}$

The Mexican Congress amended the Constitution in 2007 and 2008 to require each Mexican state to study some proposed reforms and to implement them within the state systems. ${ }^{84}$ In

HUMAN RIGHTS, supra note 3, at 17-18 ("So few cases make it to the courts because the investigations are not successful.").

77 See LAWYERS COMMITTEE FOR HUMAN RighTs, supra note 3, at 69-77 (explaining the evidentiary value of confessions); Espinoza, supra note 63, at 57-58.

78 See Espinoza, supra note 63, at 82.

79 Id. at $66,82$.

80 See LAWYERS COMMITTEE FOR HUMAN RightS, supra note 3, at 70 ("In practice, the principle of exclusion of coerced confessions from the evidence in a case or from the consideration of guilt does not have any real application. . . . [N]either the Constitution nor the criminal procedure codes explicitly establish that confessions obtained through violence, torture or coercion must be excluded altogether from the case."); Unfair Trials: Unsafe Convictions, supra note 68.

81 See Amnesty Int'l, Injustice and Impunity: Mexico's Flawed Criminal Justice System, AI Index AMR 41/001/2007, Jan. 2007; Brennan, supra note 58, at 40.

82 See Brennan, supra note 58 , at 40 .

83 See id. at $40,42$.

84 See USAID/Mexico's Role in the Merida Initiative: Hearing Before the 
March 2008, the Congress passed a new federal Criminal Procedure Code. ${ }^{85}$ Ten states are further along, with Chihuahua and Oaxaca actually conducting oral trials on a pilot basis. ${ }^{86}$

Mexico designated Proderecho (a "rule of law entity") to coordinate reforms. ${ }^{87}$ The government looked to the United States for help with reforms, so the United States Agency for International Development (USAID) is funding Proderecho and several training programs for system actors. ${ }^{88}$ Funding came through the Meridá Initiative, named for the city in the Yucatán that was the location for 2007 talks between Presidents Calderón and Bush, leading to this funding agreement. ${ }^{89}$

The first reform projects were based in the states of Chihuahua, Oaxaca, and Nuevo León. ${ }^{90}$ The emphasis there was on developing advocacy skills for prosecutors and defense attorneys to use at oral proceedings during the trial stage. ${ }^{91}$ After suitable training, lawyers on both sides are now able to question accusers, witnesses, experts, and others. ${ }^{92}$ They engage in oral advocacy on the admissibility of evidence, guilt, and sentencing. ${ }^{93}$ These reforms emphasize strong educational programs not only for the advocates, but also for judges, court personnel, police and investigators. $^{94}$

Most of Mexico's remaining states are reviewing and

Subcomm. On State, Foreign Operations, and Related Programs of the H. Comm. on Appropriations, 111 th Cong. 2 (2009) [hereinafter Hearings] (statement of Roger D. Garner, USAID Mission Director to Mexico).

85 Steven E. Hendrix, The Merida Initiative for Mexico and Central America: The New Paradigm for Security Cooperation, Attacking Organized Crime, Corruption and Violence, 5 LOY. U. CHI. INT'L L. REV. 107, 116 (2007-08).

86 Id.

87 See Brennan, supra note 58, at 41; see id.

88 See Hearings, supra note 84.

89 See Colleen W. CoOk Et. Al., Cong. Research Service, Merida Initiative: Proposed ANTICRIME and COUNTERdRug Assistance for MeXico and Central AMERICA 1 (2008); see also Cavise, supra note 66, at 788 (funding sources).

90 See Brennan, supra note 58 , at 42.

91 Id.

92 Id.

93 Id.

94 Id. 
considering these reforms to determine whether to follow suit. ${ }^{95}$ The next code revisions and training programs are targeted for Baja California Norte (BCN). ${ }^{96}$ "[BCN's] new criminal procedure code is modeled after Chihuahua's. [It] contains over 425 new articles that regulate the conduct of police, prosecutors, investigators, and courts. ...."97 $\mathrm{BCN}$ judges are also working with the Orange County (California) Superior Court to learn about court administration. ${ }^{98}$

\section{Framing the Code Revisions}

It is possible to frame these collected reforms as a movement away from an inquisitorial system, toward the adversarial model of criminal justice associated with the United Kingdom and the United States. ${ }^{99}$ Some of these reforms do indeed move Mexico away from a written procedure, toward a system that relies more on oral presentation of evidence in a public forum. ${ }^{100}$ They transform the role of defense counsel, giving the attorney more legal tools, such as due process rights that offer a basis for challenging the legitimacy of the investigation and prosecution. ${ }^{101}$

Such a framing of the reform movement might explain why the United States government has funded and endorsed the use of familiar institutions in Mexico. ${ }^{102}$ This framing, however, misses just as much as it reveals. It takes a convoluted account of inquisitorial justice to explain why moves designed to involve judges more heavily in investigations should be considered a move in the direction of adversarial justice. ${ }^{103}$

95 Id. at 44.

96 Id.

97 Id.

98 Id.

99 See Langer, supra note 43, at 618 (explaining that while the reforms take different shape they all share the transformation from the inquisitorial to the accusatorial system).

100 See Shirk \& Càzares, supra note 59, at 36 (presenting reforms implemented by former Mexican President Vincente Fox).

101 See id.

102 See Hendrix, supra note 85 , at 114 (noting that part of the Merida funding in Mexico will go towards strengthening the institutions of justice).

103 See generally Langer, supra note 43 (presenting a detailed examination of the reform movement). 
The role changes for institutional actors in Mexico bring the system closer to other Latin American systems that have crafted a distinctive "accusatorial" system, a model that alters several key features of the classic inquisitorial system without fully embracing the common law model. ${ }^{104}$ The inspiration for procedural reform in Mexico may be arriving from the South, at least as much as from the North. ${ }^{105}$

The reworking of institutional roles in Mexican criminal justice can best be understood as a balance-of-power operationcreating a competition among the actors where monopoly power once existed-not just an endorsement of a particular adversarial method of resolving factual disputes. ${ }^{106}$ A purely adversarial reform in Mexico would build a system around an oral trial, with evidence presented by two parties of equal power and opposite interests, decided by judges and juries who remain neutral between those parties. ${ }^{107}$ What is happening in Mexico, however, goes beyond the trial. The new codes limit the central importance of the prosecutor during the investigative phase. They involve the public in the investigation and trial phases by creating more open hearings and open records. ${ }^{108}$ They shift more responsibility into the hands of defense attorneys. ${ }^{109}$

While judges lose some authority over the presentation of evidence in the trial phase, they counterbalance the prosecutor during the investigative phase and retain the power to evaluate evidence at trial and to sentence offenders. The new codes enhance the distinction between the perspective and function of the prosecutor and the judge, increasing the odds that these two

104 See $i d$. at 621 (outlining the central aspects of the accusatorial system).

105 See id. at 621-26 (suggesting that Mexico reflects "triangular diffusion" of procedural concepts, starting from periphery, moving to center of developed nations for funding and endorsement, and back to periphery).

106 See, e.g., Sara Schatz et al., The Mexican Judicial System, in REFORMING THE Administration of Justice IN MEXICo (Wayne A. Cornelius \& David A. Shirk eds., 2007) 197, 221 (describing the horizontal shift in power away from the executive to include the judiciary as well).

107 See generally Langer, supra note 43, at 621 (explaining what an adversarial system looks like).

108 See Brennan, supra note 58, at 42.

109 See Brennan, supra note 58; cf. Shirk \& Càzares, supra note 59, at 17-26 (discussing the role of the prosecution before Mexico's judicial reforms). 
actors will in fact compete with one another more often. ${ }^{110}$

On the whole, these reforms in Mexico make the field more crowded. They offer more actors the power to influence the outcome at more stages of the criminal process. In this sense, Mexico is moving in the opposite direction from criminal justice systems in the United States, where competition for the administrative power of the prosecutor becomes more slight with each generation. ${ }^{111}$

\section{Cause-Effect Relationship Between Drug Violence and Procedural Reforms in Mexico}

The fact that Mexico has embarked on transformative procedural changes at the very time that drug violence is testing the legitimacy of government raises deep questions about the connection between the law and the society it serves. ${ }^{112}$ Did the violence cause the procedural change? Consider two hypotheses, each offering a different causation story.

First, we will consider the "inevitability hypothesis." According to this view, procedural reform would have happened with or without the drug violence, and the fact that they occurred at the same moment is simply a coincidence. ${ }^{113}$ Second, we will examine the "violence-as-causation" hypothesis. According to this account, the extraordinary drug violence of 2007 made possible a sweeping set of procedural changes. ${ }^{114}$ The violence was necessary to motivate actors to embrace major change. ${ }^{115}$ The initiative against drug cartels and the effort to revamp criminal

110 See generally Brennan, supra note 58, at 43 (describing how judges and lawyers are all learning how to function in a new context).

111 See Ronald F. Wright, Trial Distortion and the End of Innocence in Federal Criminal Justice, 154 U. PA. L. Rev. 79 (2005); see William T. Pizzi, Sentencing in the US: An Inquisitorial Soul in an Adversarial Body, in CRIME, PROCEDURE AND EvIDENCE IN A COMPARATIVE AND INTERNATIONAL CONTEXT 65 (John Jackson, Máximo Langer \& Peter Tillers eds., 2008).

112 Brennan, supra note 58, at 41.

113 See John J. Bailey \& Wayne A. Cornelius, Reforming the Administration of Justice in Mexico: Strategies and Requisites, in REFORMING THE ADMINISTRATION OF Justice IN MEXICo 489, 491 (Wayne A. Cornelius \& David A. Shirk eds., 2007).

114 See generally id. at 492 (describing the connections between administration of criminal justice and issues of democratic governability).

115 See Hendrix, supra note 85, at 111. 
justice were from the beginning designed as companions, joint objectives to promote a rule of law that the Mexican public would accept as legitimate. ${ }^{116}$

\section{A. The Inevitability Hypothesis}

Taking in the broad sweep of Mexican history, perhaps the criminal code revisions are happening now because of larger changes in the social structure. ${ }^{117}$ In this view, the appearance of vivid crime problems is only a distraction; these procedural changes were inevitable. ${ }^{118}$

It is commonplace among lawyers and scholars based in accusatorial systems to note that the inquisitorial systems are based on a relationship of trust between citizens and government agents. ${ }^{119}$ As a society becomes less homogenous, it will embrace more explicit declarations of rights and insist on more active checks on official power rather than relying on professionalism and tradition. ${ }^{120}$ In this telling, accusatorial justice inevitably arrives in the wake of democracy and social diversity. ${ }^{121}$ The loss of the PRI monopoly on political power with the election of Vicente Fox in 2000 signaled the arrival of a more pluralistic and democratically competitive nation. ${ }^{122}$ It was only a matter of time before the justice system, with its obvious flaws, reflected this larger social change.

Máximo Langer offers a similar account of procedural reforms in other Latin American countries. ${ }^{123}$ Fourteen Latin American countries have introduced criminal procedural reforms in the last fifteen years. ${ }^{124}$ An active network of Latin American lawyers and other experts drafted and implemented the codes, structuring the

116 Id.

117 See Langer, supra note 43, 631-51.

118 Id.

119 See Bradley, supra note 42 , at xviii ("[T]he state is the benevolent and most powerful protector and guarantor of public interest ....").

120 Id. at $\mathrm{xxi}$.

121 Id.

122 Joseph L. Klesner, The End of Mexico's One-Party Regime, 34 PoL. ScI. \& PoL. 107, 111 (2001).

123 Langer, supra note 43, at 617.

124 Id. 
changes as a movement away from inquisitorial procedures and toward accusatorial procedures. ${ }^{125}$ The network experts emphasized that this was a regional trend, and thus created a code "cascade effect." 26 Reform supporters had differing political orientations, with different priorities for the problems that accusatorial reforms should address. ${ }^{127}$ Legislatures considered the reforms to be technical, deriving from legal expert committees. ${ }^{128}$ Mostly they were adopted with little opposition. ${ }^{129}$

In the end, countries embraced the reforms when governance and public debate became more democratically competitive. ${ }^{130}$ Mexico was slow to move to embrace accusatorial justice because it was slower than Argentina and other Latin American nations to develop a democratically competitive political culture. ${ }^{131}$

Granting the explanatory power of this view of the connection between legal institutions and the political pluralism of a society, it all seemed to operate too promptly in Mexico. If Vicente Fox was elected in 2000, was an accusatorial justice system truly inevitable by 2008 , when the Congress amended the constitution? While these social dynamics may have created conditions that were favorable both for unexpected national election results ${ }^{132}$ and unprecedented procedural changes, perhaps other factors can help explain their arrival so close in time. ${ }^{133}$

\section{B. Violence-as-Causation Hypothesis}

This broad-brush talk of social and political conditions could strike some as missing the obvious and immediate connections between two major events, one following immediately after the other. ${ }^{134}$ Current crime conditions played a larger part in Mexico

\footnotetext{
125 Id.

$126 \mathrm{Id}$. at 619.

127 Id. at 661.

128 Id.

129 Id. at 662.

$130 \mathrm{Id}$. at 632 .

131 Id. at 664 .

132 See Klesner, supra note 122, at 107.

133 See Langer, supra note 43, at 633.

134 See Hendrix, supra note 85 , at 115.
} 
than in other Latin American procedural reforms. ${ }^{135}$

Perhaps the Calderón government thought of the offensive against drug cartels and the revamping of the criminal justice systems as two parts of a comprehensive strategy to promote order and the rule of law. ${ }^{136}$ The level of violence after the 2006 elections produced a clear need for the government to take visible action to fix a broken system. ${ }^{137}$ The use of an accusatorial framework was a way to signal profound change internally, ${ }^{138}$ and to encourage help and endorsement from external sources. ${ }^{139}$

Externally, the embrace of the "accusatorial" label makes the Mexican procedural changes accessible and attractive to funding sources in the United States. ${ }^{140}$ The USAID funding targeted both the law enforcement functions and the "rule of law" functions. ${ }^{141}$ Funding goes to civilian agencies for technical advice and training to strengthen institutions of justice: Vetting for new police force members; case management software to track investigations through trial,; new offices of citizen complaints and professional responsibility; and witness protection programs. ${ }^{142}$

At the same time, the accusatorial packaging of these reforms appealed to a broader external network of Latin American lawyers, judges, and activists, who aimed for more active defense and prosecution involvement in testing of evidence at trial, and more discretion for prosecutors and judges to prioritize among cases. ${ }^{143}$ The language of a party-centered adversarial criminal process long ago arrived in Mexico from the South, not from the North. ${ }^{144}$

Criminal code revisions could also serve some useful internal functions for the Calderón government. First, a more accusatorial process seemed the well-targeted answer for the problem of

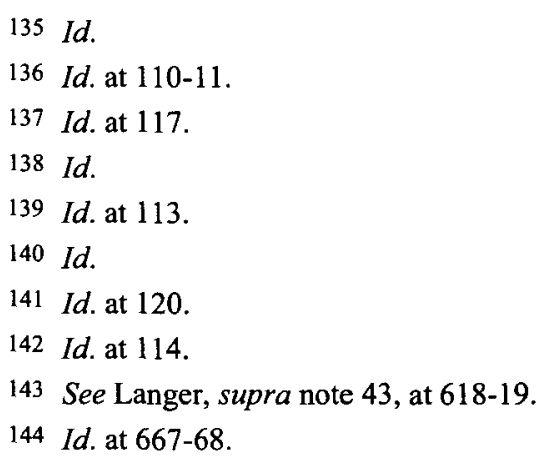


system capacity. ${ }^{145}$ Tougher law enforcement must operate together "with a justice system that can more quickly and broadly prosecute and punish criminals." 146 Increased arrests must be matched by "increased case loads to avoid the appearance of criminal impunity." ${ }^{147}$ The accusatorial system, with its emphasis on prosecutorial discretion and plea bargaining, offers a way to expand the reach of the system. ${ }^{148}$ For instance, "in Mexico's first week of . . . oral trials in the State of Chihuahua, seventy percent of forty-eight reviewed cases were resolved through one of the seven case resolution alternatives permitted by the reformed criminal codes of procedure." 149 Before the code reforms, these cases could have gone on indefinitely. ${ }^{150}$

Accusatorial reforms could also target the loss of public confidence in the Mexican system. ${ }^{151}$ It can be said that "Mexicans long ago lost faith in their judicial authorities." study reported in the New York Times found that "ninety percent of those who have been victims of a crime never reported the episode to the authorities, convinced it would do no good." Studies have also found that less than four out of every 100 people arrested are actually convicted. ${ }^{154}$ A system that depends more on lay adjudicators and public oral trials could demonstrate to its citizens that the system answers to their priorities. ${ }^{155}$

The legitimacy of government in the eyes of the publicincluding those who are the targets of government punishments-

145 Hendrix, supra note 85, at 117.

146 Id.

147 Id.

148 Id.

149 Id.

$150 \mathrm{Id}$.

151 See generally Jennifer L. Johnson, When the Poor Police Themselves: Public Insecurity and Extralegal Criminal-Justice Administration in Mexico, in LEGITIMACY AND CRiminal Justice: INTERnational Perspectives 167 (Tom R. Tyler ed., 2007) (discussing the distrust Mexico's poor has of the Mexican criminal justice system).

152 Lacey, supra note 10 , at A1.

153 Id.

154 Id.

155 See Bradley, supra note 42, at xvi; Editorial, Mexico's New Justice: A Proposed Overhaul of the Country's Court System is Good News for its People and the U.S., L.A. Times, Mar. 7, 2008, at A22 [hereinafter Mexico's New Justice]. 
is a principal goal of procedure. In the United States, years of effort to promote the concept of "community policing" and the more recent efforts to create "community prosecution" have aimed to improve broader public perceptions that the system promotes public safety while respecting local priorities and values. ${ }^{156}$ Legitimacy in the eyes of the community turns on a perception that parties can speak and be heard, and that officials treat parties equally without favoritism. ${ }^{157}$

Will the ongoing revisions to Mexican criminal codes create more public confidence and legitimize the system in their eyes? This is not a question one can answer in the abstract. While the efficiencies of an accusatorial system may create a more timely system that appears more responsive to public concerns, the tradition of prosecutorial discretion opens up the danger of unequal or unexplained treatment of cases. ${ }^{158}$ Reforms that empower defense counsel to confront witnesses and test prosecutor case quality will only be valuable if the lawyer seizes a fleeting moment at trial. Could not a written record offer more reliable chances to point out inconsistencies and weaknesses?

In some ways, the inquisitorial system-with its expectation that judges explain all their decisions in writing-might promote public confidence more easily than an accusatorial system. ${ }^{159}$ Certainly a U.S.-style system that relies overwhelmingly on guilty pleas obtained from defendants who would pay an enormous penalty for going to trial is far from ideal as a way to develop and

156 Dan M. Kahan, Reciprocity, Collective Action, and Community Policing, 90 CAL. L. Rev. 1513, 1527-28 (2002). See Kay L. Levine, The New Prosecution, 40 WAKE FOREST L. REV. 1125 (2005) (examining the societal implications of the shift from the traditional prosecutorial focus on convictions to the new prosecutorial focus on crime reduction). See generally Walter J. Dickey \& Peggy A. McGarry, The Search for Justice and Safety Through Community Engagement: Community Justice and Community Prosecution, 42 IDAHO L. REV. 313 (2006) (exploring how cities across the United States are integrating community justice and community prosecution with the tradition role of public law enforcement).

157 See TOM R. Tyler, Why PeOPle Obey the LAW 5-6 (1990); Tracey Meares, The Legitimacy of Police Among Young African-American Men, 92 MARQ. L. REV. 651, 659 (2009); Tom R. Tyler \& Jeffrey Fagan, Legitimacy and Cooperation: Why Do People Help the Police Fight Crime in their Communities?, 6 OHIO ST. J. CRIM. L. 231, 239 (2008).

158 See Mexico's New Justice, supra note 155.

159 See Bradley, supra note 42, at xvi-xvii. 
test a full and accurate factual record. ${ }^{160}$

While there is no inherent advantage in the package of new procedures that Mexico is now embracing, the newness of these procedures offers an advantage. Just as it was important to replace police officers in Mexico-perceived as corrupt at every levelwith more widely-trusted soldiers from the armed forces, so it is important to replace an older, distnusted judicial system with something that is perceived as a clean sweep. ${ }^{161}$ In the long run, replacement of police forces with armed forces might create more problems than it solves, but the move does reset an intolerable status quo. ${ }^{162}$ The same might be said of criminal code revisions that create more charging discretion and open the door for more plea bargaining. ${ }^{163}$

\section{Conclusion: Federalism and the Legitimacy Question in Mexico}

There is an encouraging and intriguing aspect of the foundational procedural changes happening in Mexico: which will allow for some direct comparisons. ${ }^{164}$ Since the thirty-three Mexican states will all eventually try their own reform packages, we can compare results among states. ${ }^{165}$ The reforms have started in three states and will spread to others quickly. ${ }^{166}$ If one Mexican state employs jury trials and others do not, we may very well be able to notice any effects on crime rates and legitimacy of the system. ${ }^{167}$

Furthermore, such comparisons are likely to happen in Mexico, because of the involvement of U.S. experts and funding sources for training purposes. ${ }^{168}$ Many will be watching to see whether the Mexican states start to operate, for better or worse,

160 See id. at xvii.

161 Brennan, supra note 58, at 41.

162 Lacey, supra note 10 , at A1.

163 Bradley, supra note 42, at xvii-xviii.

164 See Brennan, supra note 58, at 41.

165 See id.

166 See id. at 42.

167 See id. at 44.

168 See id. at 42. 
more like the state-level systems in the United States. ${ }^{169}$

Finally, we must keep ourselves open to the discouraging possibility that the comparisons will not matter. ${ }^{170}$ What if procedural variety all leads to the same unhappy results in crime control and legitimate outcomes? ${ }^{171}$ As lawyers and legal scholars, we must remain humble enough to say that when this many people are dying, it may not matter whether the system is accusatorial or inquisitorial. ${ }^{172}$

169 See Mexico's New Justice, supra note 155, at A22.

170 See Lacey, supra note 10, at A1.

171 See id.

172 See id. 
